\title{
Rural Livelihood Activities/Services Performed by Community Based Women Organization (CBWOs) in Imo and Rivers States, Nigeria
}

\author{
Oparaojiaku J0 ${ }^{1 *}$, Ekumankama ${ }^{2}$ and Ifenkwe GN $^{2}$ \\ ${ }^{1}$ Department of Agricultural Extension and Management, Imo State Polytechnic, Umuagwo, Ohaji, Imo State, Nigeria \\ ${ }^{2}$ Department of Rural Sociology and Extension, Michael Okpara University of Agriculture, Umudike, Umuahia, Abia State, Nigeria
}

*Corresponding author: Oparaojiaku JO, Department of Rural Sociology and Extension, Michael Okpara University of Agriculture, Umudike, Umuahia, Abia State, Nigeria.
Received Date: December 21, 2020

Published Date: January 21, 2021

\begin{abstract}
The study was undertaken to identify rural livelihood services/activities carried out by CBWOs in Imo and Rivers States. 240 CBWOs were used for the study. The major livelihood services performed by CBWOs in Imo state were women advocacy (97.6\%), weeding (97.6\%), visitation to fellow members (96.8\%), earth movement (erosion control) (95.2\%), attendance at meeting (95.2\%), sweeping (93.6\%), Agro-processing (93.6\%), Publicity (92.8\%), loading of working materials (92.0\%) and water fetching (90.4\%). In Rivers state CBWOs who played active and effective roles in supporting women advocacy (100\%), weeding (100\%), visitation to members (100\%), agro-processing (92.5\%) and earth movement (96.7\%). The overall performance of the livelihood services was in agricultural and rural development projects. This means that improving lives of members and others is a major thrust of CBWOs.
\end{abstract}

Keywords: Livelihoods; Women; Community; Organization

\section{Introduction}

Rural communities have been commonly identified in many works as the most neglected areas in developing nations [1]. Over the years, the quest for accelerated improvement in the worth of life of the communities has remained an issue of great concern to the government [1,2]. The improvement and worth of lifecycle of the community members brings change/transformation which metamorphoses to development.

The clamor for developing rural areas and providing a cushion to improve the total well-being of the communities has encouraged agricultural development. According to Ekong [3], Nigeria, like most developing countries, has periodic development plans or annual budget which spells out development programmes to be accomplished within a specific period where agricultural development features prominently. Nwosu [4] has described agricultural development as one dimension of the multi-faceted complex process of development that aims at enhancing the productive capacity of the agrarian area through the change of the rural economy from being a rustic, subsistence agricultural economy to a modern commercialized agricultural enterprise.

Food and Agricultural Organization [5] stated that in most regions of world, women in agriculture play very important role in food security as revenue recipients, nurturers and administrators of natural resources and biodiversity. Yet, all these important roles are often mitigated by constrained access to land, labor, capital and 
technology. However, food, safety and domestic well-being are clear motives for protecting or enhancing women's access and control over land and other productive resources. In addition, it is generally accepted that wealth controlled by women are conscientiously used to enhance household food security, total well-being of the family and it reduces malnutrition of the children.

Sequel to the above, Adzongo [6] also reported that in the past, women farmers were wrongly referred to as "farm laborers" or just "housewives". This signifies that their contributions were not adequately measured. But today, this perceived role is changing. Women are active in all facets of development, especially in food crop production. Food and Agricultural Organization [5], avers that rural women are responsible for half of the world's food production and have a conspicuous role in agriculture at all levels. In developing countries such as Nigeria, women produce between 60 and 80 percent of household food and they are also the world's producers of staple crops such as rice, and wheat, maize etc. which guarantees up to 90 percent food intake of the rural poor and their communities in general.

In support of the above assertion, Anikpo [7] added that women are more committed than men in agricultural activities in Sub-Saharan Africa (SSA), Nigeria inclusive. About 73\% of them are involved in cash crop production, arable and vegetable gardening, $16 \%$ in post-harvest activities and $15 \%$ in agro-forestry. Also, findings from a study financed by the United Nations Development Programme (UNDP) revealed that women make-up $60-80 \%$ of agricultural labor force in Nigeria, depending on the region, and they produce two-thirds of food crops.

FAO [8] observed thatwomen seem to haveawider socialnetwork because of their engagement in religious, cultural, agricultural and social activities which are community-based. Similarly, Ogolo [9] affirms that community participation in development programmes could be facilitated by the use of voluntary organizations such as women organizations. These organizations have been reported by Odurukwe [10] to be religious-based, service-based or sociocultural based and women organizations are more effective and play very significant roles in the actualization of the community felt needs.

Women organizations are forums where women talk about their problems and concerns; communal work activities; organize for financial assistance and seek interventions in areas of need. These organizations are avenues of empowerment when effectively explored and it extends development to women in the rural areas. It also serves as enlightenment for education on issues that boost gender participation. In IFAD - assisted projects, women earned higher status, respect and decision-making power based on their participation in groups or co-operatives. The aim is not just to interact with groups as conducts for project resources, but to help them evolve into viable, self-sustaining community organizations (International Fund for Agricultural Development, 2015).

Therefore, Community- Based Women Organizations (CBWOs), according to Wikipedia, are all such organization, institutions or congregation of people, which have local area/village-based presence, maturity and structural arrangements. In the same vein, they are civil society, non-profits organization which runs on voluntary basis and are self-funded. Many are merged, with a written constitution, having Board of Directors, while others are informal. Community Development seeks to challenge the causes and effects of poverty and inequality and offer new opportunities to those lacking choice, power and resources. Community Development empowers people and involves them in making changes they identify to be important and which when put to use, develop their skills, knowledge and experience. Community Development is about collective action. All community development projects have an anti-poverty, anti-exclusion focus and promote participation of people experiencing poverty and exclusion at all levels, work from community development principles and methods, provide support and act as a catalyst for community development activity, act as a resource in the communities of which they are part, provide coordination and co-operation between community, voluntary and statutory groups in their areas and involve representatives of groups which experience poverty and social exclusion within their management structures.

Community-based development projects (CBDP) are designed for one major purpose of improving the lives of the members both economically and socially. Because they are community based substantial involvement of the community at all stages of project increases its performance. This is because they feel part of the team and develop more ownership [11].

In Nigeria, Ogunlela \& Mukhtar [12] observed that various women groups and organizations have emerged. Such groups and organizations have contributed substantially to the gains women farmers have recorded and the voice that they now have in overall national policy on agricultural development. Example of such group is the Women Farmers Advancement Network (WOFAN), a private initiative founded in the 1990s, whose headquarters is in Kano, Nigeria. The main drive of WOFAN include providing a forum through which members of rural Nigeria communities can express themselves, formation of community groups to bring in access to agricultural credit and insurance, facilities and introducing laborsaving technologies, including modern farm implements and the use of solar energy. In addition, WOFAN also assists women farmers in their health and agricultural technology. It has since inevitably expanded to address other needs [13].

Rahman (2008) avers that the rural women played a pivotal role that is crucial to the overall success of efforts directed at 
agricultural and rural development. In addition, the position and capability of women meeting the challenges of agricultural and rural development cannot be overemphasized. They shoulder the primary responsibility for food security in Africa, yet development agencies have devoted minimal resources to researching the impact of their agricultural policies and new techniques on the well-being of Africa's women farmers. Similarly, much of Sub-Saharan Africa is matrilineal, with women's access to land being (through usufruct rights) through their husband's lineage group [14].

Thus, the major aim of this work is to identify the rural livelihood roles performed by CBWOs in Imo and Rivers States.

\section{Methodology}

The study was carried out in Imo and Rivers States. Imo has three Agricultural zones namely Owerri zone, Orlu zone and Okigwe zone. Two stage sampling technique was used in selecting CBOs. The first stage involved the random selection of four local government areas from each of the zones, to give a total of 12 local government areas. In the second stage, 10 community-based women organizations were randomly selected in the following arrangement -4 Women groups, 3 - community development unions and 3 - Co-operative societies to make up the required 10 Community Based Women Organizations per local government. On the whole 120 communitybased organizations were used for the study in Imo. Rivers State on the other hand is divided into 3 agricultural zones namely, zone I crop zone in Bori, zone II, fishing zone in Andoni, and zone III, crop/ livestock in Omuma by the Rivers State Agricultural Development Project (RISADP). Two stage sampling technique was used in selecting CBOs. The first stage involved the random selection of four local government areas from each of the zones, to give a total of 12 from Rivers State. In the second stage, 10 community-based women organizations were randomly selected in the following arrangement -4 Women groups, 3 - community development unions and 3 - Cooperative societies to make up the required 120 Community Based Organizations per local government. On the whole 240 communitybased organizations were used for the study for the two states. A total of 240 questionnaires were distributed. Data were collected by use of structured questionnaire and interview schedule and analyzed using percentages presented in frequency table.

\section{Results and Discussion}

\section{Livelihood activities/services performed by CBWOs in the study area}

Table 1 showed various livelihood services performed by CBWOs in both Imo and Rivers States. However, CBWOs Imo State played active roles in the following activities; supporting women advocacy (97.6\%) (which assist in improving respect for and the protection of women's human rights and elimination of discrimination, which in turn, is necessary to achieve full equality between men and women), weeding (97.6\%), visitation to fellow members (96.8\%), earth movement (erosion control) (95.2\%), attendance at meeting (95.2\%). Others are sweeping (93.6\%), Agro-processing (93.6\%), Publicity (92.8\%), loading of working materials (92.0\%) and water fetching (90.4\%). Furthermore, women in Imo CBWOs played a moderate role in offloading of working materials (65.6\%), planting (64.8\%), clearing (60\%), digging drainage (69.6\%) and health care support/provision to members (60\%). This is contrary to Rivers State CBWOs who played active and effective roles in supporting women advocacy (100\%), weeding (100\%), visitation to members (100\%), agro-processing (92.5\%) and earth movement (96.7\%).

Table 1: Livelihood activities/services performed by CBWOs in the study area.

\begin{tabular}{|c|c|c|c|c|}
\hline \multirow{2}{*}{$\begin{array}{c}\text { States } \\
\text { Activities/Services }\end{array}$} & \multicolumn{2}{|c|}{ Imo State } & \multicolumn{2}{|c|}{ Rivers State } \\
\hline & Frequency & Percentage & Frequency & Percentage \\
\hline Water fetching & 108 & 90.4 & 102 & 85 \\
\hline Sweeping/General Cleaning & 112 & 93.6 & 120 & 100 \\
\hline Offloading & 78 & 65 & 99 & 82.5 \\
\hline Weeding & 117 & 97.6 & 120 & 100 \\
\hline Planting & 78 & 65 & 71 & 59.2 \\
\hline Clearing & 72 & 60 & 38 & 31.7 \\
\hline Publicity & 111 & 92.8 & 120 & 100 \\
\hline Marketing of farm produce & 93 & 77.5 & 92 & 76.7 \\
\hline Loading of working materials & 110 & 92 & 60 & 50 \\
\hline Digging drainage & 83 & 69.2 & 92 & 76.7 \\
\hline Packing Sand in bags & 90 & 75 & 83 & 69.2 \\
\hline Training of members & 86 & 71.6 & 81 & 67.5 \\
\hline Agro-Processing & 112 & 93.6 & 111 & 92.5 \\
\hline Health Care provision & 60 & 50 & 65 & 54.2 \\
\hline Visitation to fellow members & 112 & 96.8 & 120 & 100 \\
\hline
\end{tabular}




\begin{tabular}{|c|c|c|c|c|}
\hline Attendance at meeting & 114 & 95.2 & 120 & 100 \\
\hline Supporting women advocacy & 117 & 97.6 & 120 & 100 \\
\hline Harvesting & 93 & 77.5 & 84 & 70 \\
\hline Fertilization & 98 & 81.6 & 87 & 72.5 \\
\hline Earth movement & 114 & 95.2 & 116 & 96.7 \\
\hline
\end{tabular}

\section{Source: Field Survey, 2019}

On the overall performance of the group, $82 \%$ of their active services were in agricultural and developmental projects, indicating high performance when compared with the expected roles. The result confirms the findings of United Nations Development Programme (2000), which observed that around the world, resilient and resourceful rural women contribute in a multitude of ways through different livelihood strategies to lifting their families and communities out of poverty. In other words, the fast-changing time has brought many new interests and responsibilities into women's orbit. Thus, the role played by women in agricultural development process is fundamental to rural development. Therefore, these roles are played in meeting the challenges of agricultural development which are crucial to the development of women and fulfillment of their economic potentials.

\section{Conclusion}

CBWOs performed several livelihood services. These were weeding, visitation to fellow members, earth movement (erosion control), attendance at meeting, sweeping, agro-processing, publicity, loading of working materials, and fetching water. The essence is bringing women together to improve their socioeconomic life, raise their standard of living and contribution to the development of their immediate communities.

\section{Acknowledgement}

None.

\section{Conflict of Interest}

No conflict of interest.

\section{References}

1. Oko O (2010) The concept of rural development: an overview; In essential issues in Rural Development. In Obasi, Oko and NnamdiErondu (eds) Nigeria. Centre for research and manpower Development (CREMD).

2. Nwosu IE (2013) Theories of Rural Development in Agricultural extension and rural Development, promoting indigenous knowledge (ed) by Ike Nwachukwu Nigeria: Lamb House Publications, Umuahia, Pp. 226.

3. Ekong EE (2003) Introduction to Rural Sociology, Dove Educational Publishers, Uyo, Nigeria.
4. Nwosu IE (2011) Agricultural Development in Nigeria: A conceptual Approach: In Rural Agricultural and Environmental Sociology in Nigeria. In Adedoyin SF (Ed) Nigeria. Andkoland publishers Nigeria Limited.

5. FAO (2003) Women in Agriculture Development Series. Gender Issues in Rural Food Security in Developing Countries, Rome, Italy.

6. Adzongo PI (2008) Gender and Healthcare policies in Agriculture and Rural Development in gender issues in Agriculture and Rural Development proceedings of the first National conference of the society for Gender in Agriculture and Rural Development held at University of Agriculture, Makurdi, Nigeria, May 26-28 (eds) MO Obasi, EP Ejembi, JB Ayoola and EE Adebayo, Pp. 244-246

7. Anikpo M (2000) Perspective in Gender Studies and Women Development Programmes. Agenda for the new Millennium. Keynote Discussion paper at the 1st Gender Studies Conference organized by the Department of English studies, University of Port Harcourt May 11-13.

8. FAO (2008) Corporate Document Repository. Gender and participating in Agricultural Development Planning www.yahoo.com.

9. Ogolo MB (1995) Grassroots participation in rural development: A study of selected infrastructure in some communities of River State. An unpublished Ph. D Thesis submitted to the Department of Agricultural Extension and Rural Development, University of Ibadan.

10. Odurukwe SN (2003) Capital formation strategies among rural women in Abia State, implications for agricultural commercialization. Paper presented at the international workshop on Gender of commercialization of small holder agriculture. Workshop jointly organized IITA and FAO between 14-16 May 2003 at IITA Ibadan.

11. Sakala SS (2004) Towards establishing sustainability of communitybased development projects. Unpublished Research report, University of St. Clements, Lusaka, Zambia.

12. Rahama AA (2011) The Role of African and Asian Women Leaders in empowering rural women in the context of rights and Development Issuese. Afro-Ashian Journal of Rural Development 44(1).

13. International Fund for Agricultural Development (IFAD) (2013) Rural Poverty Report 2013: The Challenge of ending Rural Poverty. Oxford: Oxford University Press.

14. Ogunlela YI, AA Mukhtar (n) Gender Issues in Agriculture and Rural Development in Nigeria. The Role of Women in Humanity and Social Sciences Journal 4(1): 19-30 